The Canadian Mineralogist

Vol. 38, pp. 1251-1264 (2000)

\title{
THE ASSOCIATION OF PLATINUM-GROUP MINERALS IN PLACERS OF THE PUSTAYA RIVER, KAMCHATKA, RUSSIA
}

\author{
NADEZHDA D. TOLSTYKH ${ }^{\S}$ \\ United Institute of Geology, Geophysics and Mineralogy, Siberian Branch, Russian Academy of Sciences, \\ prosp. Koptyuga, 3, 630090 Novosibirsk, Russia \\ EVGENIY G. SIDOROV ${ }^{\S}$
}

Koryak Geology Mining Company, bl. Pijpa, 9, 683006 Petropavlovsk-Kamchatskiy, Russia

KAUKO V.O. LAAJOKI ${ }^{\S}$

Department of Geology, University of Oulu, PL3000, FIN-90401 Oulu, Finland

ALEKSANDR P. KRIVENKO AND MAKSIM PODLIPSKIY

United Institute of Geology, Geophysics and Mineralogy, Siberian Branch, Russian Academy of Sciences, prosp. Koptyuga, 3, 630090 Novosibirsk, Russia

\begin{abstract}
We have studied the platinum-group minerals (PGM) recovered from the Pustaya River placer deposit, situated within the Koryak-Kamchatka platinum-bearing belt of Alaskan-type intrusions in eastern Russia. The specific features of the geochemistry of the PGM of this placer deposit characterize the ore-forming system in the Alaskan-type source, which was partly eroded. The PGM concentrate (160 grains) consists of platinum nuggets, except for two grains, an iridium nugget and Pd-bearing gold (15.18\% $\mathrm{Pd})$. The platinum nuggets are represented by native platinum, isoferroplatinum and $\mathrm{Pt}-\mathrm{Fe}$ alloy with an elevated concentration of $\mathrm{Pd}$ (up to $9.52 \mathrm{wt}$ \%). Some nuggets are surrounded by rims of $\mathrm{PtCu}, \mathrm{Pt}_{3} \mathrm{Cu}$, or $\mathrm{PtS}$ composition. Osmium, cooperite, vysotskite, platarsite, hollingworthite, irarsite, sperrylite, keithconnite, stibiopalladinite, rhodarsenide, vasilite, rhodian pyrrhotite and unnamed phases $\mathrm{Pd}_{2} \mathrm{Te},(\mathrm{Pt}, \mathrm{Pd})_{3} \mathrm{~S}_{2},(\mathrm{Pt}, \mathrm{Pd}, \mathrm{Fe}, \mathrm{Cu})_{3} \mathrm{~S}$, and $(\mathrm{Cu}, \mathrm{Fe}, \mathrm{Pd}, \mathrm{Pt}, \mathrm{Rh})_{9} \mathrm{~S}_{8}$ occur as inclusions in the platinum nuggets. The oreforming system is characterized by a depletion in $\mathrm{Os}$, Ir, and $\mathrm{Ru}$, and enrichment in $\mathrm{Pd}$ and $\mathrm{Cu}$ at the late-magmatic stage and $\mathrm{Cu}$ at the hydrothermal-metasomatic stage. Enrichment of the melt in Pd produced Pd-rich Pt-Fe alloys. Residual portions of the melt enriched in $\mathrm{S}, \mathrm{Pd}$ and $\mathrm{Cu}$ filled gas vacuoles in platinum nuggets, in which the further crystallization of multi-phase parageneses [vysotskite, vasilite, $(\mathrm{Pt}, \mathrm{Pd})_{3} \mathrm{~S}_{2},(\mathrm{Pt}, \mathrm{Pd}, \mathrm{Fe}, \mathrm{Cu})_{3} \mathrm{~S},(\mathrm{Cu}, \mathrm{Fe}, \mathrm{Pd}, \mathrm{Pt}, \mathrm{Rh}, \mathrm{Ru})_{9} \mathrm{~S}_{8}$, bornite and chalcopyrite] occurred. Further hydrothermal-metasomatic transformations led to the appearance of hongshiite and cooperite rims on platinum.
\end{abstract}

Keywords: platinum-group minerals, placer deposits, Pt-Fe-Pd alloys, PGM inclusions, Alaskan-type intrusions, KoryakKamchatka belt, Russia.

\section{SOMMAIRE}

Nous avons étudié les minéraux du groupe du platine dans un concentré alluvionnaire du gisement en placer de la rivière Pustaya, qui traverse la ceinture Koryak-Kamchatka de complexes platinifères de type Alaska, dans la partie orientale de la Russie. Les caractéristiques géochimiques des minéraux du groupe du platine témoignent des attributs de la minéralisation associée à une socle contenant des complexes ignés de type Alaska, maintenant en partie érodés. Le concentré contient 158 pépites de platine, une pépite d'iridium et une autre d'or palladifère $(15.18 \% \mathrm{Pd})$. Les pépites de platine contiennent platine natif, isoferroplatine et un alliage $\mathrm{Pt}-\mathrm{Fe}$ ayant une concentration élevée de $\mathrm{Pd}$ (jusqu'à 9.52\%, poids). Certaines pépites montrent une bordure de $\mathrm{PtCu}, \mathrm{Pt}_{3} \mathrm{Cu}$, ou PtS. Osmium, cooperite, vysotskite, platarsite, hollingworthite, irarsite, sperrylite, keithconnite, stibiopalladinite, rhodarsenide, vasilite, pyrrhotite rhodifère et les phases sans nom $\mathrm{Pd}_{2} \mathrm{Te},(\mathrm{Pt}, \mathrm{Pd})_{3} \mathrm{~S}{ }_{2},(\mathrm{Pt}, \mathrm{Pd}, \mathrm{Fe}, \mathrm{Cu})_{3} \mathrm{~S}$, et $(\mathrm{Cu}, \mathrm{Fe}, \mathrm{Pd}, \mathrm{Pt}, \mathrm{Rh})_{9} \mathrm{~S}_{8}$ sont incluses dans les pépites de platine. A la source, la minéralisation mène à de faibles teneurs en $\mathrm{Os}$, Ir, et $\mathrm{Ru}$, et un enrichissement en $\mathrm{Pd}$ et $\mathrm{Cu}$ à un stade tardi-magmatique, et en $\mathrm{Cu}$ au stade hydrothermal-métasomatique. L'enrichissement du magma en Pd explique la formation de l'alliage Pt-Fe palladifère. Des portions résiduelles du magma

§_E-mail address: tolst@uiggm.nsc.ru,kec@mail.iks.ru, laajoki@sveka.oulu.fi 
enrichi en $\mathrm{S}$, $\mathrm{Pd}$ et $\mathrm{Cu}$ piégées dans les vacuoles des pépites de platine ont donné une paragenèse multi-phasée [vysotskite, vasilite, $(\mathrm{Pt}, \mathrm{Pd})_{3} \mathrm{~S}_{2}$, $(\mathrm{Pt}, \mathrm{Pd}, \mathrm{Fe}, \mathrm{Cu})_{3} \mathrm{~S},(\mathrm{Cu}, \mathrm{Fe}, \mathrm{Pd}, \mathrm{Pt}, \mathrm{Rh}, \mathrm{Ru})_{9} \mathrm{~S}_{8}$, bornite et chalcopyrite]. Les transformations hydrothermalesmétasomatiques ont produit des liserés de hongshiite et de cooperite sur le platine.

(Traduit par la Rédaction)

Mots-clés: minéraux du groupe du platine, gisements alluvionnaires (en placers), alliage Pt-Fe-Pd, inclusions, intrusion de type Alaska, ceinture Koryak-Kamchatka, Russie.

\section{INTRODUCTION}

Concentrically zoned clinopyroxenite-dunite massifs of the Uralian or Alaskan type commonly are a source of rich platinum-bearing placers. We have studied the PGM from placers of the Pustaya River basin, the source of which are slightly eroded Uralian or Alaskan-type massifs. These massifs are part of the extensive Pt-bearing Koryak-Kamchatka belt. The dependence of platinum mineralization on the level of erosion has been discussed by many investigators, but the information reported in many cases is contradictory. Shashkin \& Botova (1989) claimed that there is a tendency for the Ir and Os contents of the Pt-Fe alloy to increase with increasing proportion of wehrlite and clinopyroxenite in the massif, i.e., with decreasing level of erosion. Ac- cording to Nekrasov et al. (1991), isoferroplatinum in the upper horizons of the massifs is enriched in $\mathrm{Pd}$ and Os, and depleted in Ir and Fe. Our data allow us not only to provide additional information on the UralianAlaskan type of PGM occurrences in a poorly studied region, but also to characterize the paragenesis of platinum-group minerals from the placers associated with slightly eroded gabbro - clinopyroxenite - dunite massifs.

\section{The Geological Context}

The area under study occurs within the KoryakKamchatka platinum-bearing belt, which has been recognized in the last decade only. It is located in the northwestern part of Circum-Pacific belt (Fig. 1) and is

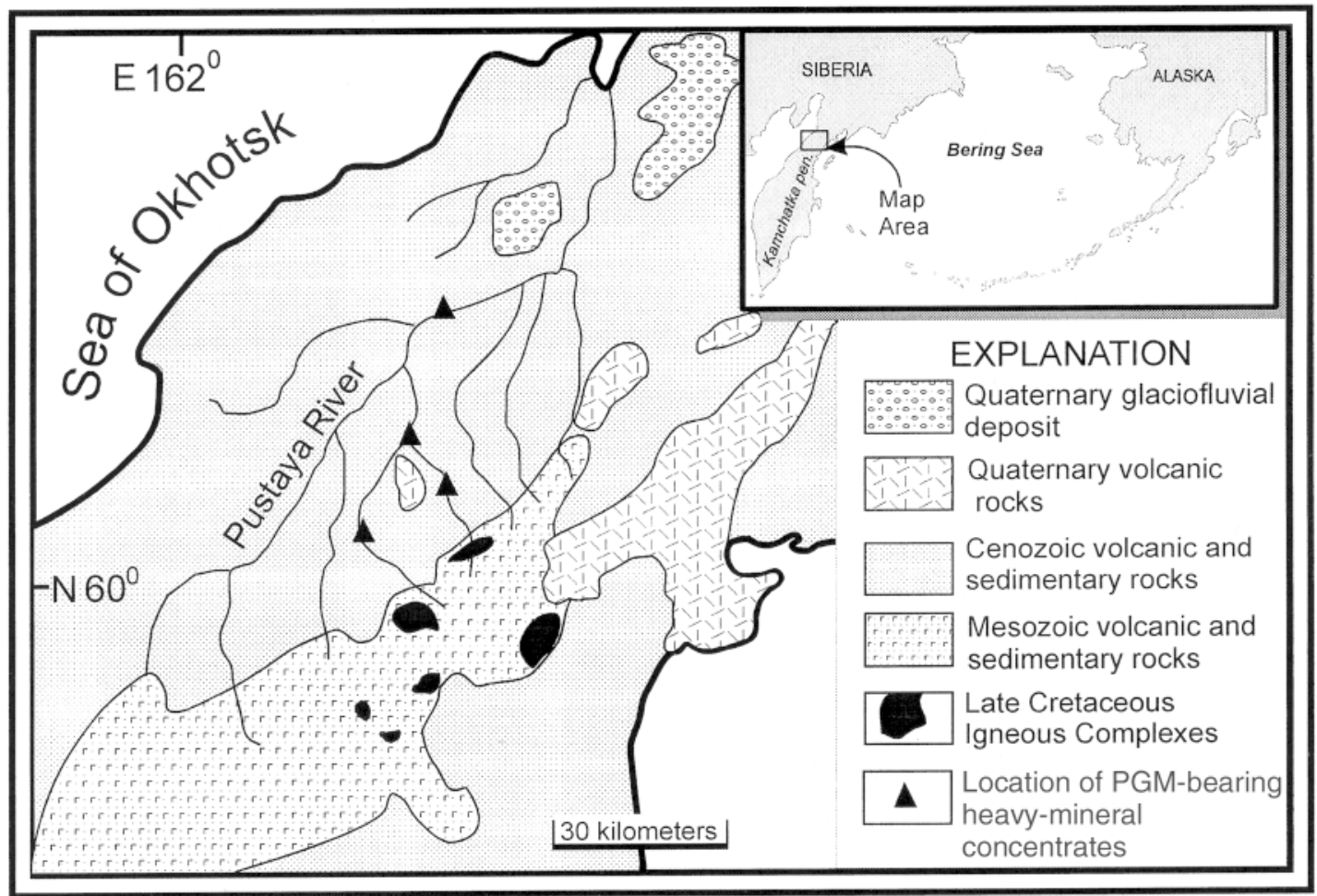

FIG. 1. Simplified geological map of the Pustaya River area in the Kamchatka Peninsula. 
a zone of intensive exploitation of platinum placers (Sidorov 1995, Zaitsev et al. 1998, Kozin et al. 1999). The chemical composition of the rocks and the profile of mineralization in the Koryak-Kamchatka Pt-bearing belt are comparable to those in the classic belts of concentrically zoned massifs in the Urals and southeastern Alaska, but this belt is rather poorly studied (Kurtyev et al. 1991). It extends about $1000 \mathrm{~km}$ from the central part of the Kamchatka Peninsula to the eastern part of the Koryak Highland, and consists of discrete outcrops of gabbro - pyroxenite - dunite massifs (Sidorov et al. 1997). In a modern structural model, the massifs are considered bodies exposed in the frontal zones of large regional overthrusts onto Upper Cretaceous and Paleogene volcanogenic deposits (Batanova \& Astrakhantsev 1994).

The structure of the massifs follows the classic scheme: at its periphery, a dunite core grades into clinopyroxenite, which then is surrounded by a gabbro shell (Kutyev et al. 1991). Such a zonation may be absent, however, depending on the evolution of the massifs, tectonic conditions of the occurrence, and degree of erosion. Slightly eroded massifs exist near the Pustaya River basin, emplaced in Upper Cretaceous volcanosedimentary deposits. The proportion of dunite and peridotite in the massifs is here negligible. The predominant rocks are magnetite-bearing pyroxenites, which have elevated contents of platinum-group elements, mainly palladium (to $1 \mathrm{ppm}$ ). Platinum-group minerals (PGM) were obtained from heavy-mineral concentrates taken from alluvial deposits in tributary streams of the Pustaya River, which drain areas of outcrops of massifs of the same type. We have studied the mineral composition of 160 grains of PGM separated from such heavy-mineral concentrates.

\section{Platinum-Group Minerals from the Placers of THE PUSTAya River}

In the alluvium of the Pustaya River, the PGM consist mostly $(99.5 \%)$ of platinum nuggets in the form of flattened rounded grains up to $2 \mathrm{~mm}$ in size and occasionally of irregular shape or with crystallographically indexable faces. Nonrounded, hackly grains are scarce. These grains are coated by chlorite and hydroxides of $\mathrm{Fe}$ and $\mathrm{Mn}$. Inclusions in the nuggets consist of clinopyroxene, biotite, and chlorite. The platinum nuggets were studied in reflected light in polished sections. Some of them are surrounded by a gray rim and filled with inclusions localized along cracks and rims of grains. The majority of inclusions are filled by round droplet-like gas cavities. Among platinum nuggets, only one grain of iridium about $0.8 \mathrm{~mm}$ in size was found.

The composition of the PGM was determined with a Camebax-Micro electron microprobe, using the RMA92 program (L.N. Pospelova and V.M. Chubarov, analysts). The acceleration voltage was $20 \mathrm{kV}$, the beam current, 20-30 $\mu \mathrm{A}$, with a counting time of 10 seconds for each analytical line. We used Pt, Ir, Os, Pd, Rh, Ru, Au metals, $\mathrm{CuFeS}_{2}$ (for $\mathrm{Cu}, \mathrm{Fe}, \mathrm{S}$ ), InAs (for As), PbTe (for $\mathrm{Te}$ ) and $\mathrm{CuSbS}_{2}$ (for $\mathrm{Sb}$ ) as standards. The following X-ray lines were used: $L \alpha$ for Pt, Ir, $\mathrm{Pd}, \mathrm{Rh}, \mathrm{Ru}, \mathrm{Au}$, $\mathrm{As}, \mathrm{Sb}$, and $\mathrm{Te}, K \alpha$ for $\mathrm{S}, \mathrm{Fe}$, and $\mathrm{Cu}$, and $M \alpha$ for Os. The interference of lines was corrected for with the help of the data file of experimental calculated coefficients (Lavrent'ev \& Usova 1994).

\section{$(\mathrm{Pt}-\mathrm{Fe}-\mathrm{Cu}-\mathrm{Pd})$ alloys}

More than 150 nuggets were analyzed. Results of the microprobe analyses (Table 1) showed the following compositions of minerals and solid solutions: $(\mathrm{Pt}, \mathrm{Fe})$, $\mathrm{Pt}_{3} \mathrm{Fe},(\mathrm{Pt}, \mathrm{Pd}, \mathrm{Fe}),(\mathrm{Pt}, \mathrm{Fe}, \mathrm{Cu}), \mathrm{Pt}_{3} \mathrm{Cu}$, and $\mathrm{PtCu}$. On the basis of $\mathrm{Pt}: \mathrm{Fe}$ ratio and the classification of Cabri \& Feather (1975), three varieties are distinguished: native platinum, which is predominant, isoferroplatinum and Pt-Fe alloy (Figs. 2a, b). Native platinum carries up to 12.26 wt.\% total of $\mathrm{Pd}, \mathrm{Rh}, \mathrm{Ir}, \mathrm{Ru}$, and Os; isoferroplatinum carries up to $2.20 \mathrm{wt} \%$ of these elements, whereas Pt-Fe alloy contains mere traces (Fig. 2b). Some analyses show significant concentrations of $\mathrm{Pd}$ (up to 9.52 wt.\%, or 14 at.\%; Fig. 3), in some cases exceeding the Fe content in the platinum alloy. Minor concentrations of $\mathrm{Os}, \mathrm{Ir}, \mathrm{Ru}$ and $\mathrm{Rh}$ (up to $c a$. $1.5 \mathrm{wt} . \%$ each) are invariably present (Table 1). Platinum with such a high Pd content was earlier found in the placers of northern Burma (Hagen et al. 1990), Saskatchewan

TABLE 1. SELECTED COMPOSITIONS OF THE PGE ALLOYS, PUSTAYA RIVER PLACER DEPOSIT, KAMCHATKA, RUSSIA

\begin{tabular}{|c|c|c|c|c|c|c|c|c|c|}
\hline Anal. & $\mathrm{Pt}$ & Ir & Os & $\mathrm{Pd}$ & $\mathbf{R h}$ & $\mathrm{Ru}$ & $\mathrm{Fe}$ & $\mathrm{Cu}$ & Total \\
\hline 1 & 82.41 & 0.82 & 0.61 & 9.52 & 1.07 & 0.25 & 4.68 & 0.81 & 100.17 \\
\hline 2 & 82.68 & 0.72 & 0.70 & 8.82 & 0.74 & 0.14 & 4.65 & 0.85 & 99.30 \\
\hline 3 & 82.89 & 0.00 & 0.57 & 8.01 & 0.69 & 0.00 & 4.90 & 1.05 & 98.10 \\
\hline 4 & 86.45 & 0.00 & 0.00 & 6.45 & 0.00 & 0.00 & 4.74 & 0.31 & 97.95 \\
\hline 5 & 96.41 & 0.00 & 0.00 & 0.00 & 0.00 & 0.00 & 3.59 & 0.41 & 100.41 \\
\hline 6 & 87.85 & 1.05 & 1.10 & 2.14 & 1.04 & 0.16 & 4.80 & 0.81 & 98.95 \\
\hline 7 & 88.24 & 1.45 & 1.01 & 1.01 & 1.24 & 0.37 & 4.83 & 0.53 & 98.68 \\
\hline 8 & 88.67 & 0.00 & 0.16 & 4.44 & 0.00 & 0.00 & 5.18 & 0.70 & 99.15 \\
\hline 9 & 89.42 & 0.27 & 0.60 & 1.33 & 1.54 & 0.20 & 5.21 & 0.57 & 99.14 \\
\hline 10 & 89.47 & 1.34 & 0.71 & 0.43 & 1.38 & 0.09 & 5.26 & 0.52 & 99.20 \\
\hline 11 & 88.74 & 1.01 & 0.00 & 0.22 & 0.9 & 0.06 & 8.00 & 0.56 & 99.49 \\
\hline 12 & 91.15 & 0.00 & 0.00 & 1.45 & 0.00 & 0.00 & 8.27 & 0.57 & 101.44 \\
\hline 13 & 87.56 & 0.66 & 0.07 & 0.33 & 0.58 & 0.00 & 8.93 & 0.00 & 98.13 \\
\hline 14 & 92.48 & 0.00 & 0.00 & 0.00 & 0.00 & 0.00 & 10.55 & 0.46 & 103.49 \\
\hline 15 & 85.69 & 0.00 & 0.00 & 0.00 & 0.00 & 0.00 & 12.91 & 0.06 & 98.66 \\
\hline 16 & 80.23 & 0.00 & 0.00 & 0.00 & 0.00 & 0.00 & 5.34 & 15.39 & 100.96 \\
\hline 17 & 73.87 & 0.00 & 0.50 & 0.56 & 1.22 & 0.00 & 0.68 & 20.23 & 97.06 \\
\hline 18 & 73.05 & 0.00 & 0.79 & 0.48 & 1.26 & 0.00 & 0.79 & 24.64 & 101.01 \\
\hline 19 & 86.54 & 0.00 & 0.00 & 0.01 & 0.00 & 0.00 & 1.83 & 9.23 & 97.61 \\
\hline 20 & 68.87 & 0.00 & 0.00 & 0.61 & 0.00 & 0.00 & 0.88 & 27.91 & 98.27 \\
\hline 21 & 68.45 & 0.00 & 0.00 & 0.64 & 0.00 & 0.00 & 0.53 & 29.36 & 98.98 \\
\hline 22 & 10.83 & 7.57 & 82.47 & 0.00 & 0.00 & 0.00 & 0.00 & 0.00 & 100.87 \\
\hline 23 & 1.48 & 14.59 & 81.31 & 0.00 & 0.73 & 0.31 & 0.00 & 0.00 & 98.42 \\
\hline 24 & 4.09 & 22.09 & 68.99 & 0.00 & 0.88 & 1.39 & 0.12 & 0.00 & 97.56 \\
\hline 25 & 3.83 & 74.75 & 19.97 & 0.00 & 0.00 & 0.00 & 0.00 & 0.00 & 98.55 \\
\hline
\end{tabular}

Samples: 1-10 native platinum, 11-14 isoferroplatinum, $15 \mathrm{Pt}-\mathrm{Fe}$ alloy, 16 hongshiite-tulameenite solid solution, 17,18 hongshiite, 19-21 Pt-Cu alloy, 22-24 osmium, 25 iridium. Compositions quoted in $w t \%$. 
A

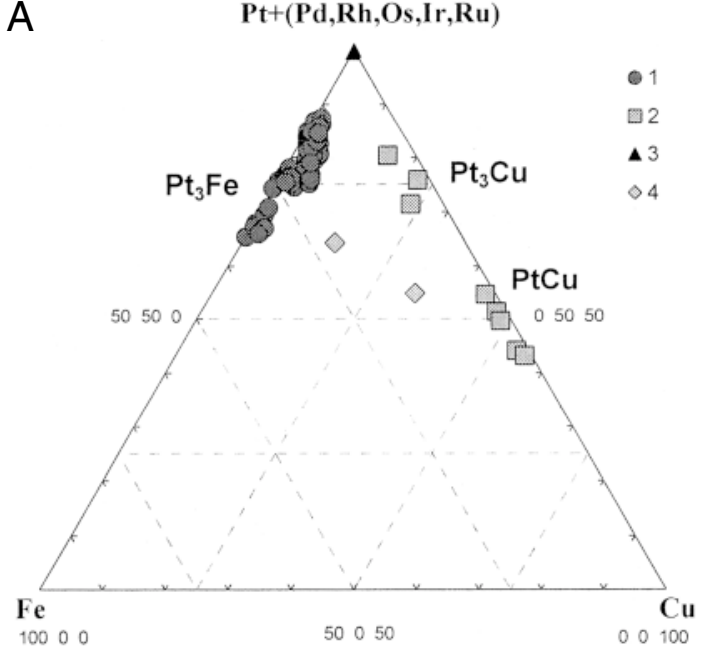

B

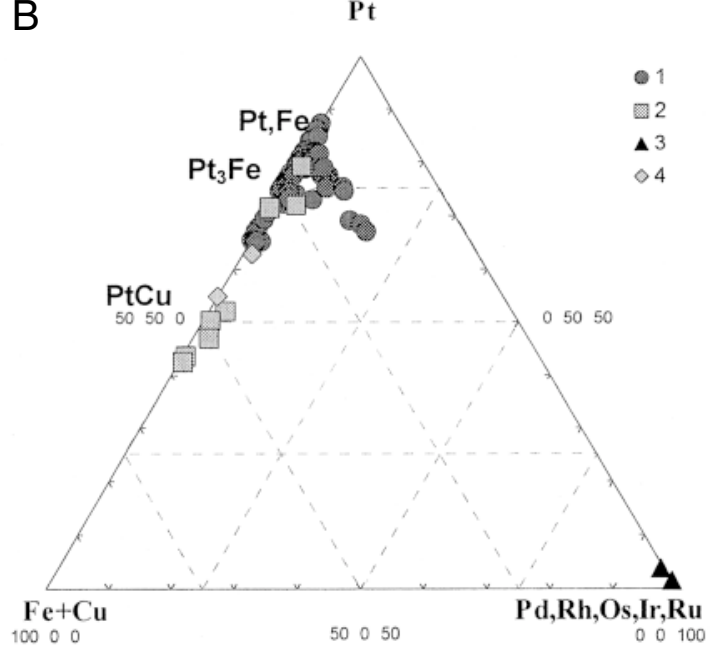

FIG. 2. Composition of PGE alloys from placer of the Pustaya River in terms of the $\mathrm{Fe}-[\mathrm{Pt}+(\mathrm{Pd}, \mathrm{Rh}, \mathrm{Os}, \mathrm{Ir}, \mathrm{Ru})]-\mathrm{Cu}(\mathrm{A})$ and of the $(\mathrm{Fe}+\mathrm{Cu})-\mathrm{Pt}-(\mathrm{Pd}, \mathrm{Rh}, \mathrm{Os}$, Ir, Ru) diagrams (B). $1 \mathrm{Pt}-\mathrm{Fe}, 2 \mathrm{Pt}-\mathrm{Cu}, 3 \mathrm{Os}-\mathrm{Ir}$, and $4 \mathrm{Pt}-\mathrm{Fe}-\mathrm{Cu}$ alloys.

River, Canada (Cabri et al. 1996), in the Krasnogorsk massif, Chukotka, Russia (Dmitrenko 1994) and in the Burguli River placer, Russia (Tolstykh et al. 1996). As for copper, it is also present in the majority of $\mathrm{Pt}-\mathrm{Fe}$ alloys, but no more than 1.5-2 wt.\%. There is also a Pt$\mathrm{Cu}$ alloy that occupies the marginal part of some $\mathrm{Pt}-\mathrm{Fe}$ nuggets. Optically, the $\mathrm{Pt}-\mathrm{Cu}$ rim does not differ from the Pt-Fe matrix, but it was detected by scanning electron microscopy (SEM) with energy-dispersion analyses, and shows a sharp boundary between the phases. Among the grains of $\mathrm{Pt}-\mathrm{Cu}$ alloy, there are compositions similar both to hongshiite $(\mathrm{PtCu})$ and the synthetic phase $\left(\mathrm{Pt}_{3} \mathrm{Cu}\right)$, and to compositions intermediate between Fe-bearing platinum and hongshiite in the system $\mathrm{Fe}(+\mathrm{Ni})-\mathrm{Pt}(+\mathrm{Pd}, \mathrm{Rh}, \mathrm{Ir}, \mathrm{Os}, \mathrm{Ru})-\mathrm{Cu}($ Fig. 2a) Hongshiite is the most widespread mineral among Pt$\mathrm{Cu}$ series of solid solutions. It was found as a rim around platinum in the placers of the Uralian (Alaskan) type and as meta-inclusions inside platinum nuggets from ophiolite placers (Tolstykh et al. 1996, 1997). Platinumcopper alloys compositionally similar to $\mathrm{Pt}_{3} \mathrm{Cu}$ were earlier described in the placers of eastern Madagascar (Legendre \& Augé 1992). Compositions richer in $\mathrm{Cu}$ were found in the Durance River placers, in France (Johan et al. 1990), Tulameen, British Columbia (Nixon et al. 1990), and in the Lukkulaisvaara massif, Russia (Barkov et al. 1992).

\section{$A u-P d-C u$ alloys}

The platinum concentrate contains only one grain of palladium-bearing gold, $120-150 \mu \mathrm{m}$ in size, with an anisotropic and homogeneous structure. The composi- tion was obtained by wavelength-dispersion (WDS) electron-microprobe analysis at the University of Oulu, Finland. It contains (wt.\%): $\mathrm{Au} 83.07, \mathrm{Cu} 3.30$ and Pd 15.18, which corresponds to the formula $\mathrm{Au}_{066} \mathrm{Pd}_{023}$ $\mathrm{Cu}_{0.08}$. Palladium-bearing gold occurs sparsely in sulfide-poor horizons of stratiform intrusions. In the Pansky massif of the Kola Peninsula, for example, the concentration of Pd in gold reaches $6.2 \mathrm{wt} . \%$, and there are also smaller amounts of Ag (Krivenko et al. 1991). Gold-palladium alloy, together with gold-platinum and gold-copper alloys, are also specific of the upper horizons of alkaline-ultrabasic massifs (e.g., Konder) and magnetite-phlogopite-bearing clinopyroxenitic bodies. In these environments, gold-palladium alloy attains

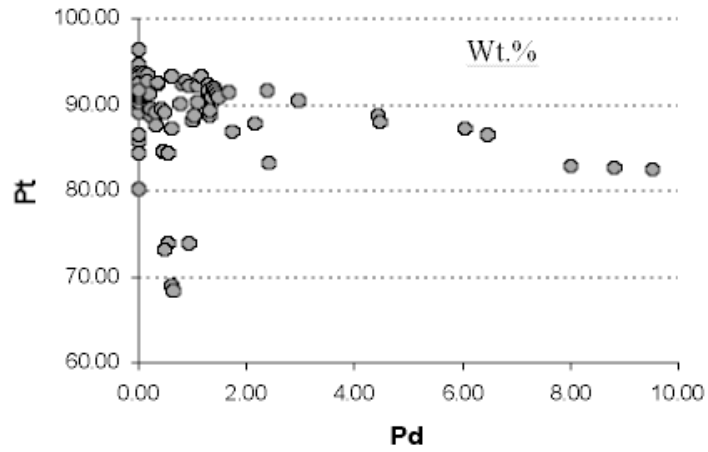

FIG. 3. Plot of $\mathrm{Pt}$ (wt.\%) versus $\mathrm{Pd}$ in the $\mathrm{Pt}-\mathrm{Fe}-\mathrm{Cu}-\mathrm{Pd}$ compounds from the Pustaya River placer. 
10.27 wt.\% $\mathrm{Pd}$, and $\mathrm{Cu}$ is present as well (Nekrasov et al. 1994).

\section{Os-Ir alloy}

Euhedral crystals of osmium of hexagonal shape (Fig. 4a) up $30 \mu \mathrm{m}$ in diameter occur as inclusions in platinum. Occasionally, the crystals are hollow, and ring-shaped in section (Fig. 4b). Compositions in terms of the system Os-Ir-Ru form an osmium trend, with iridium concentrations no more than 20 at. \%. A typical feature of native osmium from the alluvium of the Pustaya River is the low concentration of $\mathrm{Ru}(<1.39$ wt.\%) and elevated concentration of $\mathrm{Pt}$, which reaches 10 wt. \% in the system Os-Ir-Pt (Table 1, Fig. 5). Osmium with such a high Pt content is rare. It was found in the platinum placers of Colombia Choco and Chindwin River areas, Burma (Cabri et al. 1996) and Santiago River, Ecuador (Weiser \& Schmidt-Thomé 1993). Native iridium occurs as a large grain of irregular shape with an inclusion of laurite. It contains no $\mathrm{Ru}$ at all, but has about 20 at.\% Os and 4 at.\% Pt (Fig. 5).

\section{Cooperite-vysotskite}

Cooperite, $\mathrm{PtS}$, is one of the most abundant minerals described here. It covers some Pt-Fe nuggets with a thin rim, continuous or discontinuous; such a rim is in general typical of placers related to the massifs of Uralian (Alaskan) type (Tolstykh et al. 1996). The cooperite in such rims may contain minor Pd (1.77 wt.\%) and is Sdeficient compared with the ideal formula, whereas cooperite from inclusions in $\mathrm{Pt}-\mathrm{Fe}$ alloy has elevated concentrations of $\mathrm{Pd}$ (7.21 wt.\%) (Table 2). In both cases, no Ni was detected. The content of $\mathrm{Pd}$ and $\mathrm{Ni}$ in cooperite was discussed by Johan et al. (1989): cooperite related to Alaskan-type complexes contains no nickel compared to cooperite associated with basemetal sulfides in stratiform intrusions. This type of nickel-free cooperite with Pd content up to 7.9 wt.\% was also found at the Gusevogorsk deposit in the Urals.

Vysotskite, ideally PdS, was found as isolated inclusions, no bigger than $10 \mu \mathrm{m}$ in size, in platinum. The

TABLE 2. COMPOSITION OF COOPERITE AND VYSOTSKITE, PUSTAYA RIVER PLACER DEPOSIT, KAMCHATKA, RUSSIA

\begin{tabular}{lccccccl}
\hline Anal. & Pt & Pd & Cu & Os & $\mathrm{S}$ & Total & \multicolumn{1}{c}{ Formula } \\
\hline & & & & & & & \\
1 & 85.55 & 0.00 & 0.00 & 0.00 & 12.68 & 98.23 & $\mathrm{Pt}_{1.05} \mathrm{~S}_{0.95}$ \\
2 & 84.81 & 0.62 & 0.00 & 0.00 & 13.01 & 98.44 & $\left(\mathrm{Pt}_{1.03} \mathrm{Pd}_{0.01}\right)_{21.04} \mathrm{~S}_{0.96}$ \\
3 & 84.38 & 0.00 & 0.00 & 0.62 & 13.38 & 98.38 & $\left(\mathrm{Pt}_{1.01} \mathrm{Os}_{0.01}\right)_{11.02} \mathrm{~S}_{0.98}$ \\
4 & 83.44 & 1.77 & 0.00 & 0.00 & 13.35 & 98.56 & $\left(\mathrm{Pt}_{0.99} \mathrm{Pd}_{0.04}\right)_{11.03} \mathrm{~S}_{0.97}$ \\
5 & 77.76 & 7.21 & 0.00 & 0.00 & 13.46 & 98.43 & $\left(\mathrm{Pt}_{0.90} \mathrm{Pd}_{0.15}\right)_{\Sigma 1.05} \mathrm{~S}_{0.95}$ \\
6 & 30.78 & 39.04 & 5.29 & 1.48 & 22.82 & 99.41 & $\left(\mathrm{Pd}_{0.55} \mathrm{Pt}_{0.24} \mathrm{Cu}_{0.13} \mathrm{Os}_{0.01}\right)_{20.33} \mathrm{~S}_{1.07}$ \\
& & & & & & &
\end{tabular}

Samples: 1-5 cooperite, 6 vysotskite; 1-4 composition of the rims, 5,6 from inclusions. Compositions expressed in wt\%. braggite component attains 26 mol.\%, and $\mathrm{CuS}$, 14 mol.\%. The copper content ( 7 at.\%) distinguishes this mineral from the vysotskite of sulfide ores of Stillwater, Bushveld, and Norilsk, which typically contain Ni but no $\mathrm{Cu}$.

\section{Sulfarsenides of the PGE}

PGE sulfarsenides form anhedral inclusions within grains of the Pt-Fe alloy (Fig. 4d) or occur as subhedral crystals $10-20 \mu \mathrm{m}$ in size, in rims on platinum grains (Fig. 4e). Hollingworthite, RhAsS, occasionally containing $\mathrm{Pt}$ and $\mathrm{Ru}$, is predominant among sulfarsenides (Table 3). We have also analyzed platarsite, PtAsS, which contains 32 mol.\% OsAsS. The osarsite component is not common in platarsite from other occurrences of platinum placers (Cabri et al. 1996). Irarsite, ideally IrAsS, displays a strong deviation from stoichiometry. If the apparent excess As is related to the presence of $\mathrm{Pt}$ in irarsite, one can assume that the irarsite is a solid solution toward sperrylite, $\mathrm{PtAs}_{2}$.

\section{Sperrylite}

Sperrylite, $\mathrm{PtAs}_{2}$, occurs as subhedral crystals in rims on platinum grains and as fractured or brecciated segregations inside platinum grains (Fig. 4f). The former is

TABLE 3. COMPOSITION OF PGE SULFARSENIDES, (Rh,Pt,Ir)AsS, PUSTAYA RIVER PLACER DEPOSIT, KAMCHATKA, RUSSIA

\begin{tabular}{lrrrrrrrrr}
\hline Anal. & Pt & Ir & Rh & Os & Ru & Fe & As & S & Total \\
\hline & & & & & & & & & \\
1 & 1.42 & 0.00 & 48.33 & 0.05 & 0.00 & 0.14 & 33.70 & 15.23 & 98.87 \\
2 & 0.00 & 0.00 & 48.59 & 0.07 & 0.00 & 0.00 & 33.31 & 15.21 & 97.18 \\
3 & 11.95 & 0.00 & 34.43 & 0.16 & 5.77 & 0.12 & 32.65 & 14.27 & 99.35 \\
4 & 28.85 & 0.00 & 9.12 & 21.66 & 0.08 & 0.25 & 28.48 & 10.82 & 99.26 \\
5 & 16.26 & 39.91 & 0.48 & 7.40 & 0.39 & 0.26 & 27.82 & 6.90 & 99.42
\end{tabular}

Structural formulae: 1. $\left(\mathrm{Rh}_{1.00} \mathrm{Pt}_{0.02} \mathrm{Fe}_{0.01}\right)_{\Sigma 1.03} \mathrm{As}_{0.96} \mathrm{~S}_{1.01}, 2$ 2. $\mathrm{Rh}_{1.02} \mathrm{As}_{0.96} \mathrm{~S}_{1.02}, 3$. $\left(\mathrm{Rh}_{0.75} \mathrm{Pt}_{0.14} \mathrm{Ru}_{0.13}\right)_{\Sigma_{1.02}} \mathrm{As}_{0.98} \mathrm{~S}_{1.00}, \quad$ 4. $\left(\mathrm{Pt}_{0.41} \mathrm{Os}_{0.32} \mathrm{Rh}_{0.25} \mathrm{Fe}_{0.01}\right)_{\mathbf{2} 0.99} \mathrm{As}_{1.06} \mathrm{~S}_{0.94}, 5$. $\left(\mathrm{Ir}_{0.67} \mathrm{Pt}_{0.27} \mathrm{Os}_{0.13} \mathrm{Fe}_{0.02} \mathrm{Rh}_{0.02} \mathrm{Ru}_{0.01}\right)_{\Sigma 1.12} \mathrm{As}_{1.20} \mathrm{~S}_{0.70}$. Samples: 1-3 hollingworthite, 4 platarsite, 5 irarsite. Compositions expressed in wt\%.
TABLE 4. COMPOSITION OF SPERRYLITE, PtAs, PUSTAYA RIVER PLACER DEPOSIT, KAMCHATKA, RUSSIA

\begin{tabular}{lccccccccc}
\hline Anal. & Pt & Pd & Rh & Ir & Fe & As & S & Sb & Total \\
& & & & & & & & & \\
\hline 1 & 56.54 & 0.00 & 0.21 & 0.00 & 0.13 & 42.24 & 0.39 & 0.00 & 99.51 \\
2 & 49.04 & 0.15 & 3.83 & 2.16 & 0.00 & 41.73 & 1.51 & 0.32 & 98.74 \\
3 & 50.23 & 0.00 & 3.73 & 1.19 & 0.00 & 41.71 & 1.27 & 0.49 & 98.62 \\
4 & 49.70 & 0.00 & 4.83 & 0.00 & 0.10 & 40.70 & 1.56 & 0.00 & 97.44
\end{tabular}

Structural formulae: 1. $\left(\mathrm{Pt}_{1.00} \mathrm{Fe}_{0.01} \mathrm{Rh}_{0.01}\right)_{\Sigma 1.02}\left(\mathrm{As}_{1.94} \mathrm{~S}_{0.04}\right)_{\Sigma 1.98}$, 2. $\left(\mathrm{Pt}_{0.83} \mathrm{Rh}_{0.12} \mathrm{Ir}_{0.04}\right)_{\Sigma 1.02}$

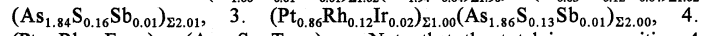
$\left(\mathrm{Pt}_{0.85} \mathrm{Rh}_{0.16} \mathrm{Fe}_{0.01}\right)_{\Sigma 1.02}\left(\mathrm{As}_{1.81} \mathrm{~S}_{0.16} \mathrm{Te}_{0.01}\right)_{\Sigma 1.98}$. Note that the total in composition 4 includes $0.55 \mathrm{wt} \%$ Te. Compositions expressed in wt $\%$. 

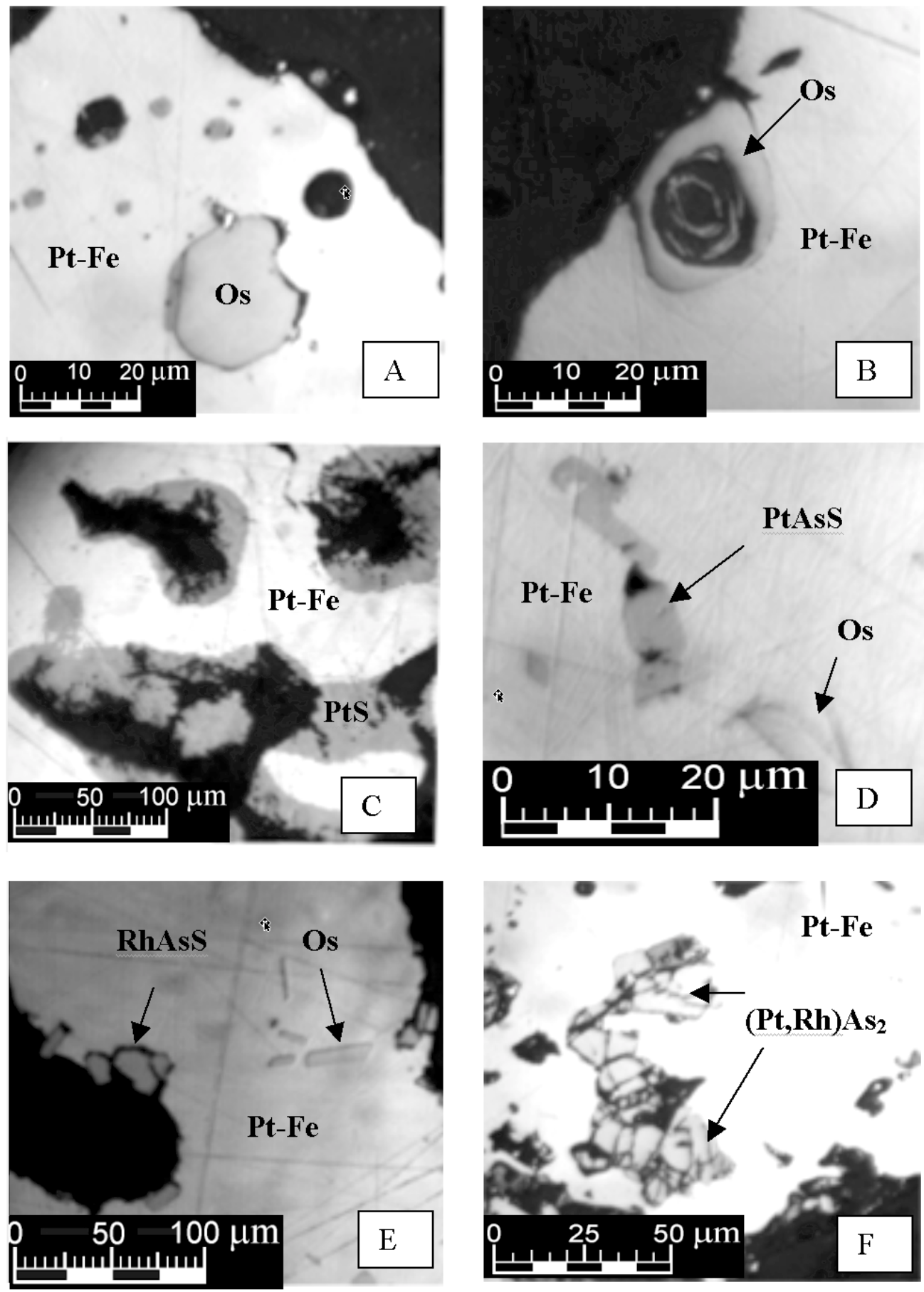

FIG. 4. Scanning electron microscope images of PGM intergrowths. A. Osmium inclusion (Os) in the Pt-Fe nugget. Sulfide microparagenesis partly filling a gas vacuole (dark). B. Osmium inclusion (Os) in the Pt-Fe nugget. C. Pt-Fe nugget replaced by cooperite $(\mathrm{PtS})$. D. Euhedral osmium crystal $(\mathrm{Os})$ and negative platarsite inclusions (PtAsS) in the Pt-Fe nugget. E. Marginal crystals of hollingworthite (RhAsS) and Os inclusions in the Pt-Fe alloy. F. Inclusions of Rh-bearing sperrylite $(\mathrm{Pt}, \mathrm{Rh}) \mathrm{As}_{2}$ in $\mathrm{Pt}-\mathrm{Fe}$ nugget. 


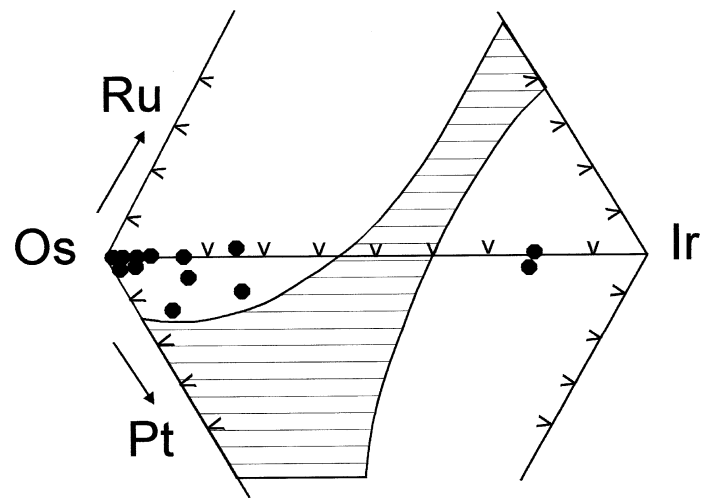

FIG. 5. Composition of osmium and iridium in the Pustaya River suite in terms of the Os-Ru-Ir-Pt plot.

stoichiometric, with minor amounts of $\mathrm{Rh}, \mathrm{Fe}$ and $\mathrm{S}$. The latter reaches Rh 4.83, Ir 2.16, and S 1.56 (in wt.\%). We have also found $\mathrm{Sb}$ and $\mathrm{Te}$ in the sperrylite (Table 4). In reflected light at high magnification, the mineral looks homogeneous. Rhodium-bearing sperrylite has been encountered before at Witwatersrand (3.5 wt.\% Rh) (Feather 1976), in the Nomgon stratiform intrusion in Mongolia (to 12 wt.\% Rh: Izokh et al. 1992), in the Krasnogorsk massif, Koryakiya, in Russia (to $12 \mathrm{wt} . \%$ Rh: Dmitrenko 1994) and in the placer of Gornaya Shoria, where the sperrylite contains 6.5 wt.\% Rh (Krivenko et al. 1994). In our case, the amount of Rh and $\mathrm{Ir}$ is proportional to the amount of $\mathrm{S}$ and excess of As. The same regularity is observed for sperrylite from the Krasnogorsk massif (Dmitrenko 1994). One may assume that sperrylite with an elevated concentration of $\mathrm{Rh}$ is a solid solution toward hollingworthite (e.g., $\mathrm{PtAs}_{2}$ - RhAsS): note that these two minerals have the same structure. The chemical formulas of sperrylite (Table 4, nos. 2-4) indicate that it contains $14-17$ mol.\% of the hollingworthite-irarsite component.

\section{Phases of the Pd-Te system}

Keithconnite, $\mathrm{Pd}_{3-x} \mathrm{Te}$, and unnamed phase $\mathrm{Pd}_{2} \mathrm{Te}$ were found as two-phase inclusions about $10 \mu \mathrm{m}$ in size in a round cavity in a platinum nugget. According to Cabri et al. (1979), the stoichiometry of keithconnite does vary $(0.14<x<0.43)$. At Pustaya River, keithconnite has a composition within the above-mentioned range, with $x$ being equal to 0.32 (Table 5). It contains 3.19 wt.\% $\mathrm{Pt}$ and traces of $\mathrm{Rh}, \mathrm{Fe}$, and As. Keithconnite with up to $1.73 \mathrm{wt}$.\% Pt was described as inclusions in platinum nuggets in a placer in eastern Madagascar (Legendre \& Augé 1992, Augé \& Legendre 1992), as well as in the placers of Burma, at Chindwin River (2.45 wt.\% Pt) and Colombia Choco (2.41 wt.\% Pt: Cabri et al. 1996). The unnamed phase $\mathrm{Pd}_{2} \mathrm{Te}$ has a stoichiometry similar to that of a synthetic compound proposed in the system Pd-Te (El-Boragy \& Schubert 1971). A natural compound, $\mathrm{Pd}_{2}(\mathrm{Te}, \mathrm{As})$, has been reported by Daltry \& Wilson (1997), though not the locality, and is similar to the phase under discussion.

Stibiopalladinite, $P d_{5+x} S b_{2-x}$

Stibiopalladinite has been found in one inclusion only, in a platinum nugget about $15 \mu \mathrm{m}$ across. Its composition corresponds to the formula $(\mathrm{Pd}, \mathrm{Pt})_{5+x} \mathrm{Sb}_{2-x}$, in which Pt accounts for 21.95 wt.\% (19 mol.\% $\mathrm{Pt}_{5} \mathrm{Sb}_{2}$ ) (Table 5). Stibiopalladinite from the Jubdo placer, in Ethiopia, contains 19 wt.\% Pt (Evstigneeva et al. 1992), which is similar to stibiopalladinite from the Burmese placers at Chindwin River (up to $16.37 \mathrm{wt} \% \mathrm{Pt}$ ) and Colombia Choco (up to 10.5 wt.\% Pt: Cabri et al. 1996). Stibiopalladinite commonly occurs in sulfide ores (Cabri \& Laflamme 1981) and is related to ophiolite massifs (Augé \& Maurizot 1995). In both of those cases, the proportion of platinum in stibiopalladinite amounts to no more than a few percent. It is possible that the high concentration of $\mathrm{Pt}$ in stibiopalladinite is a feature of certain geological conditions related to the Alaskan-type intrusions.

\section{Rhodarsenide, $(R h, P d)_{2} A s$}

A phase of stoichiometry PdRhAs, possibly pertaining to rhodarsenide, was found as several inclusions of 5 to $20 \mu \mathrm{m}$ in size within one nugget of platinum. The inclusions have a roundish and elongate shape, grayish cream color, and strong anisotropy. The composition of three analyzed inclusions is homogeneous and corresponds to the formula $\mathrm{Pd}_{1+x} \mathrm{RhAs}_{1-x}$, where $0.07<x<$ 0.09 . The grains show the persistent presence of Pt (up to $5.90 \mathrm{wt} . \%$ ) and $\mathrm{Sb}$ (up to $1.32 \mathrm{wt} \%$ ), whereas minor concentrations of $\mathrm{Cu}$ and $\mathrm{Fe}$ are present (Table 6). Rhodarsenide, as a mineral species, was discovered recently (Tarkian et al. 1997) on the Vilyui River in central Siberia, and it was assigned a formula $(\mathrm{Rh}, \mathrm{Pd})_{2} \mathrm{As}$ on the basis of the predominance of $\mathrm{Rh}$ over $\mathrm{Pd}$ and because of variable proportions of these elements. Before this, rhodarsenide was found as an unnamed phase

TABLE 5. COMPOSITION OF KEITHCONNITE, $\mathrm{Pd}_{3-x} \mathrm{Te}$, UNNAMED PHASE Pd $\mathrm{Pd}_{2} \mathrm{Te}$ AND STIBIOPALLADINITE, $\mathrm{Pd}_{5} \mathrm{Sb}_{2}$, PUSTAYA RIVER PLACER DEPOSIT, KAMCHATKA, RUSSIA

\begin{tabular}{lccccccrr}
\hline Anal. & Pd & Pt & Rh & Fe & Te & As & Sb & Total \\
\hline & & & & & & & & \\
1 & 67.31 & 3.19 & 0.13 & 0.11 & 30.45 & 0.32 & 0.00 & 101.51 \\
2 & 60.05 & 5.29 & 0.37 & 0.00 & 35.81 & 0.40 & 0.00 & 101.92 \\
3 & 50.23 & 21.95 & 0.00 & 0.17 & 0.00 & 0.00 & 27.35 & 99.70
\end{tabular}

Structural formulae: 1. $\left(\mathrm{Pd}_{2.60} \mathrm{Pt}_{0.07} \mathrm{Fe}_{0.01} \mathrm{Rh}_{0.01}\right)_{\Sigma 2.69}\left(\mathrm{Te}_{0.98} \mathrm{As}_{0.02}\right)_{\Sigma 1.00}$,

2. $\left(\mathrm{Pd}_{1.92} \mathrm{Pt}_{0.09} \mathrm{Rh}_{0.01}\right)_{\Sigma 2.02}\left(\mathrm{Te}_{0.96} \mathrm{As}_{0.02}\right)_{\Sigma 0.98}$, 3. $\left(\mathrm{Pd}_{4.07} \mathrm{Pt}_{0.97} \mathrm{Fe}_{0.03}\right)_{\Sigma 5.07} \mathrm{Sb}_{1.93}$. Samples: 1 keithconnite, 2 unnamed $\mathrm{Pd}_{2}$ Te phase, 3 stibiopalladinite. Compositions expressed in $w t \%$. 
TABLE 6. COMPOSITION OF RHODARSENIDE (Rh,Pd $)_{2} \mathrm{As}$, PUSTAYA RIVER PLACER DEPOSIT, KAMCHATKA, RUSSIA

\begin{tabular}{lcccccccc}
\hline Anal. & Pd & Rh & Pt & Fe & Cu & As & Sb & Total \\
\hline & & & & & & & & \\
1 & 35.41 & 35.08 & 4.82 & 0.00 & 0.38 & 22.80 & 1.32 & 99.81 \\
2 & 34.41 & 34.87 & 5.74 & 0.09 & 0.39 & 22.65 & 1.24 & 99.39 \\
3 & 34.53 & 34.78 & 5.90 & 0.11 & 0.46 & 22.48 & 1.27 & 99.53 \\
\hline
\end{tabular}

Structural formulae: 1. $\left(\mathrm{Pd}_{0.98} \mathrm{Pt}_{0.07} \mathrm{Cu}_{0.02}\right)_{\Sigma 1.07} \mathrm{Rh}_{1.00}\left(\mathrm{As}_{0.89} \mathrm{Sb}_{0.03}\right)_{\Sigma 0.92}$ 2. $\left(\mathrm{Pd}_{0.96} \mathrm{Pt}_{0.09} \mathrm{Cu}_{0.02}\right)_{\Sigma 1.09} \mathrm{Rh}_{1.00}\left(\mathrm{As}_{0.90} \mathrm{Sb}_{0.03}\right)_{\Sigma 0.93}$,

3. $\left(\mathrm{Pd}_{0.96} \mathrm{Pt}_{0.09} \mathrm{Cu}_{0.02} \mathrm{Fe}_{0.01}\right)_{\Sigma 1.08} \mathrm{Rh}_{1.00}\left(\mathrm{As}_{0.89} \mathrm{Sb}_{0.03}\right)_{\Sigma 0.92}$

Compositions expressed in wt\%.

in Fifield, Australia, as inclusions in isoferroplatinum, and its composition was determined to be $\mathrm{Pd}_{5} \mathrm{Rh}_{5} \mathrm{As}_{4}$ (Johan et al. 1991). Inclusions of PdRhAs were also recognized in isoferroplatinum of the Krasnogorsk massif in Koryakia (Dmitrenko et al. 1994). Moreover, in the platinum placers on the Chukotka River, Gornostayev et al. (1999) described the compound $(\mathrm{Rh}, \mathrm{Pd}, \mathrm{Pt})_{2} \mathrm{As}$. The composition of all compounds is reported in terms of the $\mathrm{Pd}-\mathrm{Rh}-\mathrm{As}$ diagram (Fig. 6). Compared with rhodarsenide from Vilyui, the mineral under study and all other occurrences exhibit equal proportions of $\mathrm{Pd}$ and $\mathrm{Rh}$ and, in some cases, a partial replacement of platinum by palladium (up to $5.9 \mathrm{wt} . \%$ in rhodarsenide from the Pustaya River and up to 20.7 wt.\% in Chukotka). Rhodarsenide from an ophiolite source, in contrast, contains $\mathrm{Ir}$ and $\mathrm{Ru}$ in substitution for Rh (Agafonov et al. 1998).

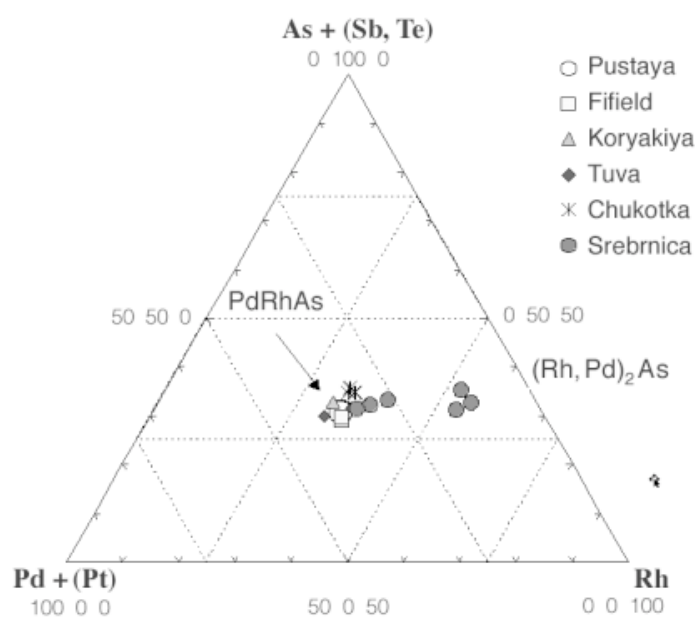

FIG. 6. Plot of composition of rhodarsenide, (Rh,Pd $)_{2} \mathrm{As}$, from Srebrnica (Tarkian et al. 1997) and of PdRhAs from the placer of Pustaya River, Fifield (Johan et al. 1991), Koryakiya (Dmitrenko1994), Tuva (Agafonov et al. 1998) and Chukotka (Gornostayev 1994).

\section{$P t-P d-$ base metal sulfides}

The platinum nuggets are characterized by an abundance of cavities, round, isometric, and drop-like in section, some of which are filled with multiphase inclusions of sulfide minerals. Unnamed sulfides of stoichiometry $M e_{3} \mathrm{~S}_{2}, M e_{3} \mathrm{~S}, M e_{1-x} \mathrm{~S}, M e_{9} \mathrm{~S}_{8}$ (Me: PGE, Cu, Fe) have been found in such multiphase inclusions inside round and drop-like cavities in platinum nuggets, as intergrowths with each other and with chalcopyrite and bornite. One of the inclusions is a symplectitic intergrowth of small inclusions of $\mathrm{Pt}$ and $\mathrm{Pd}$ sulfides in a bornite matrix (Figs. 7a, b).
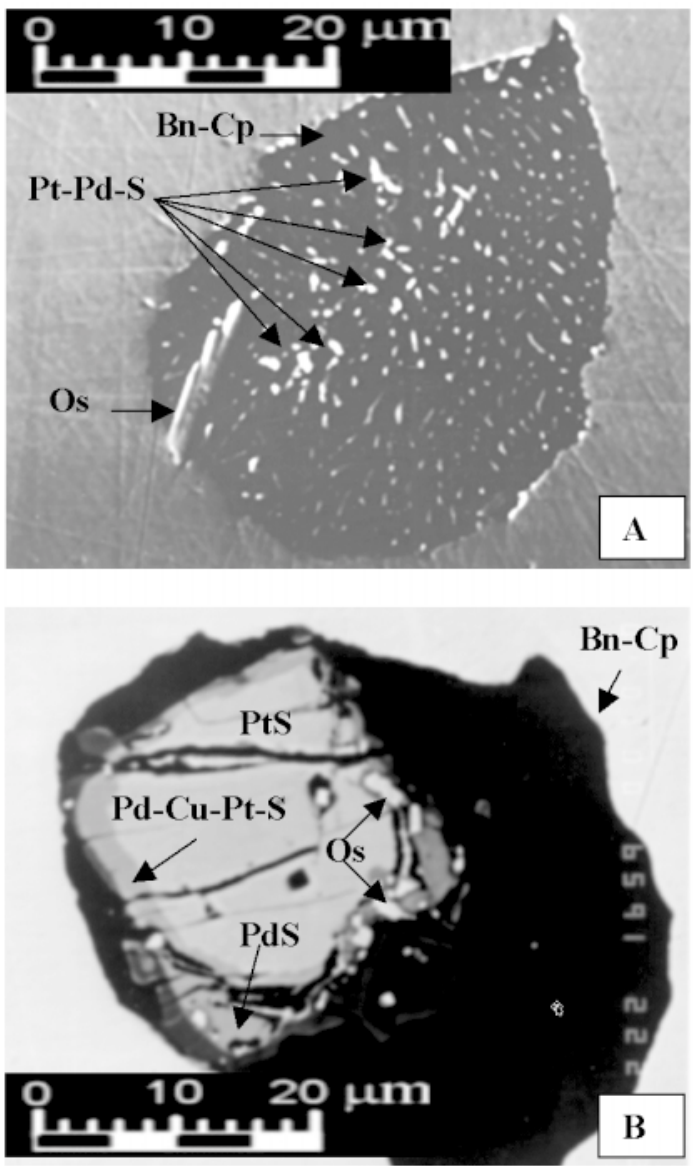

FIG. 7. Back-scattered electron images taken with a scanning electron microscope of the sulfide-dominant microparagenesis filling a gas vacuole. A. Exsolution texture of Pt$\mathrm{Pd}-\mathrm{S}$ particles (light) and euhedral crystal of osmium in chalcopyrite-bornite matrix (dark). B. Cooperite crystal surrounded by $\mathrm{Pd}-\mathrm{Cu}-\mathrm{Pt}-\mathrm{S}$ phase (vasilite?), vysotskite and osmium laths (white) in chalcopyrite-bornite matrix (dark). 
Euhedral crystals of $(\mathrm{Pt}, \mathrm{Pd})_{3} \mathrm{~S}_{2}$, of grayish cream color, are no bigger than $10 \mu \mathrm{m}$ and weakly anisotropic. The compositions of two crystals, included in two nuggets, are rather homogeneous (Table 7, Nos. 1, 2). Platinum predominates over palladium; $\mathrm{Fe}, \mathrm{Cu}$, and $\mathrm{Rh}$ are present up to $3.34,0.46$, and $0.30 \mathrm{wt} . \%$, respectively. No similar synthetic compound is known in the system Pt-Pd-S at 800 and $1000^{\circ} \mathrm{C}$ (Skinner et al. 1976, Cabri et al. 1978). Perhaps it formed at a lower temperature than $800^{\circ} \mathrm{C}$. A similar phase, $(\mathrm{Pt}, \mathrm{Pd}, \mathrm{Rh}, \mathrm{Os}, \mathrm{Au}, \mathrm{Cu})_{3} \mathrm{~S}_{2}$, was found in eastern Madagascar (Legendre \& Augé $1992)$, and $(\mathrm{Pt}, \mathrm{Cu}, \mathrm{Rh}, \mathrm{Pt})_{3} \mathrm{~S}_{2}$ was reported in an inclusion in platinum in the Durance River placer (Johan $e t$ al. 1990).

The compounds $(\mathrm{Pd}, \mathrm{Cu}, \mathrm{Pt})_{3} \mathrm{~S}$ and $(\mathrm{Pt}, \mathrm{Pd}, \mathrm{Fe}, \mathrm{Cu})_{3} \mathrm{~S}$ form segregations of irregular shape, in some cases of flame shape, intergrown with euhedral crystals of $(\mathrm{Pt}, \mathrm{Pd})_{3} \mathrm{~S}_{2}$ in a chalcopyrite or bornite matrix in the microparageneses of a multiphase inclusion. In reflected light, they are cream-gray and weakly anisotropic. In one of the inclusion, the proportion of Pd strongly predominates over $\mathrm{Pt}$, and the concentration of $\mathrm{Cu}$ is very significant. In another case, $\mathrm{Pt}$ and $\mathrm{Pd}$ as well as $\mathrm{Cu}$ and Fe are approximately in equal proportions (Table 7, Nos. $3,4)$, but the $M e / \mathrm{S}$ value for both compounds is $1: 3$. Such compounds are unknown in the system Pt-Pd-S, but if they are considered in terms of the system Pd$\mathrm{Cu}-\mathrm{S}$, on the phase diagram constructed at $550^{\circ} \mathrm{C}$ (Matkovic et al. 1976), then one of the compositions

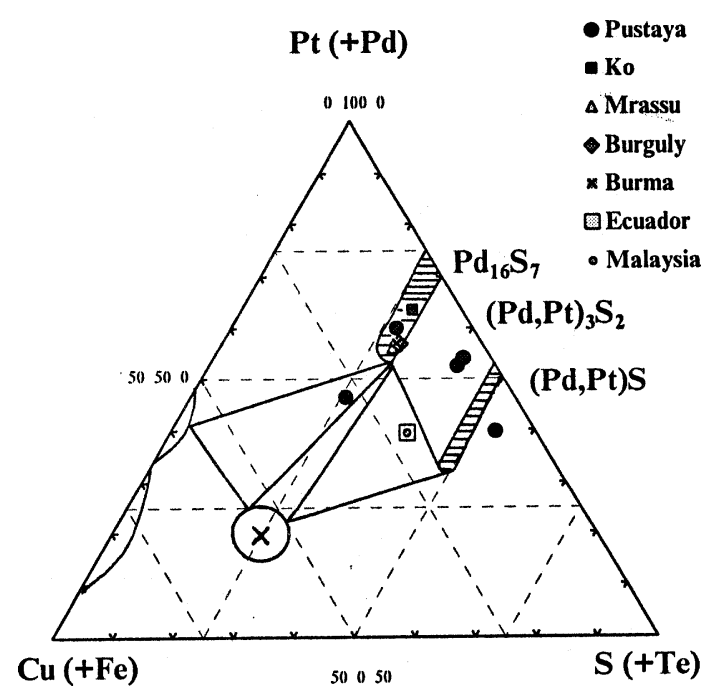

FIG. 8. Composition of Pd-Pt-Cu sulfides from the placers of the Pustaya River, the Ko, Mrassu, and Burguly rivers (Tolstykh \& Krivenko 1994), the northern Burma placers (Hagen et al. 1990), and the Santiago River (Ecuador) and Borneo (Malaysia) placers (Cabri et al. 1996), projected on the phase diagram at $550^{\circ} \mathrm{C}$ (after Matkovic et al. 1976). falls in the stability field of $\mathrm{Pd}_{16} \mathrm{~S}_{7}$, corresponding to vasilite (Atanasov 1990) (Fig. 8). The breadth of this field allows some deviation from the ratio 16:7. Because of this possibility, many unnamed phases found earlier fall into the stability field of vasilite $\mathrm{Pd}_{16} \mathrm{~S}_{7}$ in spite of their different stoichiometry, as is the case for $(\mathrm{Pd}$, $\mathrm{Cu}, \mathrm{Pt})_{3} \mathrm{~S}$ from the Pustaya River, For example, the compositions $(\mathrm{Pd}, \mathrm{Cu}, \mathrm{Fe})_{5} \mathrm{~S}_{2}$ from the alluvium of the Ko River in East Sayan, $\mathrm{Pd}_{4} \mathrm{CuS}_{2}$ from the Mrassu River in Kuznetsk Alatau, $(\mathrm{Pd}, \mathrm{Pt})_{4} \mathrm{CuS}_{2}$ from the Burguli placer in the Amur region (Tolstykh \& Krivenko 1994), having a stoichiometry 5:2 with some substitution involving $\mathrm{Pt}, \mathrm{Pd}, \mathrm{Cu}$ and $\mathrm{Fe}$, as well as $\mathrm{Pd}_{7} \mathrm{Cu}_{2} \mathrm{~S}_{4}$ from northern Burma (Hagen et al. 1990) and $\mathrm{Pd}_{3} \mathrm{CuS}_{2}$ from Ecuador (Cabri et al. 1996), all lie in the stability field of the synthetic phase $\mathrm{Pd}_{16} \mathrm{~S}_{7}$, corresponding to vasilite. The second unnamed phase from the Pustaya River, $(\mathrm{Pt}, \mathrm{Pd}, \mathrm{Fe}, \mathrm{Cu})_{3} \mathrm{~S}$, lies on the extension of this field into the copper-rich part of the diagram (Fig. 8).

The phase $(\mathrm{Cu}, \mathrm{Fe}, \mathrm{Pd}, \mathrm{Pt}, \mathrm{Rh}, \mathrm{Ru})_{9} \mathrm{~S}_{8}$ was found intergrown with the above-described sulfides in multiphase inclusions. It is violet-brown and strongly anisotropic. Its composition corresponds to an intermediate solid-solution $(\mathrm{Cu}, \mathrm{Fe})_{1+x} \mathrm{~S}$, Iss, in the nickel-free part of the synthetic system $\mathrm{Fe}-\mathrm{Cu}-\mathrm{Ni}-\mathrm{S}$, which, as shown experimentally, is the main host of Pd (Peregoedova 1999). However, according to that author, this Iss does not quench, and decomposes at $550^{\circ} \mathrm{C}$ into Pdenriched pentlandite, copper-bearing minerals, and independent Pd phases (vysotskite and vasilite). This is what we observe texturally in the microparageneses. Nevertheless, the phase under study is intermediate be-

TABLE 7. COMPOSITION OF VASILITE $(\mathrm{Pd}, \mathrm{Cu}, \mathrm{Pt})_{3} \mathrm{~S}$ AND UNNAMED (Pt,Pd, Cu,Fe) $)_{3} \mathrm{~S}$ AND $(\mathrm{Pt}, \mathrm{Pd})_{3} \mathrm{~S}_{2}$ PHASES, PUSTAYA RIVER PLACER DEPOSIT, KAMCHATKA, RUSSIA

\begin{tabular}{lllllllll}
\hline Anal. & Pt & Fe & Pd & Te & Rh & S & Cu & Total \\
\hline & & & & & & & & \\
1 & 55.43 & 3.34 & 26.93 & 0.00 & 0.28 & 13.60 & 0.33 & 99.91 \\
2 & 55.72 & 2.12 & 26.54 & 0.00 & 0.30 & 13.24 & 0.46 & 98.38 \\
3 & 16.43 & 1.14 & 65.26 & 0.57 & 0.06 & 10.06 & 8.00 & 101.52 \\
4 & 47.31 & 8.35 & 25.31 & 0.00 & 0.00 & 8.61 & 8.89 & 98.47 \\
\hline
\end{tabular}

1. $\left(\mathrm{Pt}_{1.38} \mathrm{Pd}_{1.23} \mathrm{Fe}_{0.29} \mathrm{Cu}_{0.02} \mathrm{Rh}_{0.01}\right)_{\Sigma 2.93} \mathrm{~S}_{2.06}$, 2. $\left(\mathrm{Pt}_{1.43} \mathrm{Pd}_{1.25} \mathrm{Fe}_{0.19} \mathrm{Cu}_{0.04} \mathrm{Rh}_{0.01}\right)_{\Sigma 2.92} \mathrm{~S}_{2.07}$, 3. $\left(\mathrm{Pd}_{2.11} \mathrm{Cu}_{0.43} \mathrm{Pt}_{0.29} \mathrm{Fe}_{0.07}\right)_{\Sigma 2.90}\left(\mathrm{~S}_{1.08} \mathrm{Te}_{0.02}\right)_{\mathrm{\Sigma} 1.10}, 4$. $\left(\mathrm{Pt}_{0.93} \mathrm{Pd}_{0.92} \mathrm{Fe}_{0.58} \mathrm{Cu}_{0.54}\right)_{\Sigma 2.97} \mathrm{~S}_{1.03}$. Compositions expressed in $w t \%$.

TABLE 8. COMPOSITION OF PGE-BEARING BASE-METAL SULFIDES, PUSTAYA RIVER PLACER DEPOSIT, KAMCHATKA, RUSSIA

\begin{tabular}{lcrrrrrrrr}
\hline Anal. & Fe & Cu & Pt & Pd & Rh & Os & Ru & S & Total \\
\hline & & & & & & & & & \\
1 & 47.53 & 2.55 & 1.61 & 0.00 & 11.94 & 0.73 & 0.29 & 34.41 & 99.06 \\
2 & 17.11 & 21.42 & 16.17 & 10.55 & 4.18 & 0.89 & 1.62 & 25.70 & 97.64
\end{tabular}

1. $\left(\mathrm{Fe}_{0.79} \mathrm{Rh}_{0.11} \mathrm{Cu}_{0.04} \mathrm{Pt}_{0.01}\right)_{20.95} \mathrm{~S}_{1.00}, 2 .\left(\mathrm{Cu}_{3.39} \mathrm{Fe}_{3.09} \mathrm{Pd}_{1.00} \mathrm{Pt}_{0.83} \mathrm{Rh}_{0.41} \mathrm{Ru}_{0.16} \mathrm{Os}_{0.05}\right)_{28.93} \mathrm{~S}_{8.07}$. Samples: $1 \mathrm{Me}_{1-\mathrm{x}} \mathrm{S}, 2 \mathrm{Me}_{9} \mathrm{~S}_{8}$. Compositions expressed in $\mathrm{wt} \%$. 
tween the copper-bearing analogue of pentlandite and kharaelakhite (Table 8). It is known that in common pentlandite at $700^{\circ} \mathrm{C}$ the $\mathrm{PGE} / \mathrm{BM}$ ratio is less than 0.13 at maximum dissolution of PGE (Makovicky et al. 1986). In kharaelakhite, this ratio is greater than 1 (Genkin et al. 1985). In our phase, the ratio PGE:BM is 0.37 .

Rhodian pyrrhotite $(\mathrm{Fe}, \mathrm{Rh})_{1-x} \mathrm{~S}$ is observed as single blebs localized in isometric cavities of platinum grains. Its $\mathrm{Ru}$ content is 11.94 wt.\%, whereas $\mathrm{Pt}$, Os, and $\mathrm{Ru}$ are present in lesser amounts (Table 8). "Complex" $M e_{1-x} \mathrm{~S}$ sulfides with the stoichiometry of pyrrhotite seem widespread; for example, Rh-bearing pyrrhotite with $29.38 \% \mathrm{Rh}$ is found on the Ko River in East Sayan (Tolstykh \& Krivenko 1994). According to experimental studies (Makovicky et al. 1986), pyrrhotite dissolves $6.7 \mathrm{wt} . \% \mathrm{Rh}$ at $500^{\circ} \mathrm{C}$, and $44 \mathrm{wt} . \%$ at $900^{\circ} \mathrm{C}$ without any transformations, according to X-ray-diffraction data. According to Distler et al. (1977), "pyrrhotite" contains $40 \mathrm{wt} \% \mathrm{Rh}$ at $760^{\circ} \mathrm{C}$. If we suppose the crystallization of rhodian pyrrhotite from a residual sulfide melt, the Pustaya River material could have formed at a temperature slightly above $500^{\circ} \mathrm{C}$.

\section{Discussion: Chemical Features OF THE ORE-Forming SySTEM}

Refractory elements, especially $\mathrm{Ru}$, are of minor significance in the assemblages of PGM in the Pustaya placers. The PGM formed from a melt depleted in Os, Ir, and Ru. Except for one grain of iridium, the PGM concentrate consists of Pt-based alloys. Other PGM are subordinate as inclusions and rims. The inclusions of Os are tiny, and their composition lacks $\mathrm{Ru}$. The minerals of the $\mathrm{RuS}_{2}-\mathrm{OsS}_{2}$ series, which commonly are mentioned in connection with Alaskan-type massifs (Cabri et al. 1996, Evstigneeva et al. 1992, Tolstykh \& Krivenko 1997), are absent. In the PGE arsenides, the proportion of $\mathrm{Ru}$ is negligible. The depletion of the oregenerating system in iridium explains the absence of $\mathrm{Pt}-$ Ir unmixing typical, for example, of Inagli (Tolstykh \& Krivenko 1997). The fractionation of a phase or phases enriched in refractory elements probably takes place at the early magmatic stage of ore segregation (Nekrasov et al. 1994). The area of accumulation of such earlyformed Os-Ir-Ru minerals was not subject to erosion, and was not the source of the Pustaya placer.

The ore-forming system is Pd-enriched; the concentration of $\mathrm{Pd}$ in the alloys reaches 10 at.\%. This fact suggests that the $\mathrm{Pt}-\mathrm{Fe}-\mathrm{Pd}$ alloys formed from a residual Pd-enriched melt at the late magmatic stage near the apical parts of the massifs. Nekrasov et al. (1994) reported that palladium occurs mainly in the apical part of a massif and in marginal facies; the palladium concentration in $\mathrm{Pt}-\mathrm{Fe}$ alloys is, in this way, more typical of weakly eroded massifs. This finding supports the assumption that the Pustaya placer is related to the apical part of such an intrusive body.
Copper is enriched at a late stage of crystallization, and its enrichment does not correlate with that of $\mathrm{Pd}$, as is indicated by the presence of a $\mathrm{Pt}-\mathrm{Cu}$ rim free of $\mathrm{Pd}$. The Pt-Fe matrix is enriched in $\mathrm{Pd}$, which suggests that matrix and rim formed at different times. The $\mathrm{Pt}-\mathrm{Cu}$ rims were formed as a result of a hydrothermal-metasomatic process, rather than from a change in conditions of magmatic crystallization. The above-mentioned individual features of the ore-forming system differ from those exhibited in the Durance (Johan et al. 1990) and Konder (Nekrasov et al. 1994) examples, where the level of $\mathrm{Pd}$ does correlate with $\mathrm{Cu}$, and a $\mathrm{Pt}-\mathrm{Pd}-\mathrm{Cu}$ alloy does occur.

The role of the sulfur was more important than that of arsenic at the hydrothermal-metasomatic stage. We observed a reaction rim of cooperite only on platinum, unlike the sperrylite-cooperite rims in the platinum placers of Kuznetsk Alatau. Only the lamellae of osmium in platinum nuggets can be considered to be primary magmatic inclusions with confidence. Phases of Os appearing in a combination of multiphase inclusions formed late. Other inclusions, judging from their morphology and relationship to platinum, formed after its crystallization. In spite of the euhedral habit of the sperrylite and hollingworthite inclusions, their occurrence in the rim of platinum grains and cracks indicates their hydrothermal-metasomatic mode of formation.

The cavities, which are filled with multiphase inclusions of sulfide minerals, are vacuoles, which, most likely, are a result of gas bubbles. We suggest that the ore-forming residual melt enriched in volatile components (gas-saturated fluid) produced these multiphase inclusions. Similarly, platinum in the Uralian deposits was found to contain a great number of cavities, which occupied $13 \%$ of the volume and reduced the density of the PGM (Betekhtin 1935). The gas filling these vacuoles may have been released from metal-organic complexes, which may thus have played a significant part in the mobilization and transport of the PGE (Slobodskoy 1981). The abundance of gas vacuoles in platinum also indicates that crystallization occurred in the apical part of intrusive bodies.

Multiphase inclusions in these cavities are the most interesting ones. They are the product of crystallization of a residual melt and subsequent subsolidus transformations of early phases, which after crystallization of the main metallic phases became enriched in $\mathrm{Pd}, \mathrm{Rh}$, $\mathrm{Cu}$, and $\mathrm{S}$, and further evolved in closed systems in gas vacuoles. These can be considered small natural autoclaves. The phases filling the cavities in platinum nuggets from the Pustaya River are the products of decomposition of high-temperature base-metal sulfide solid-solutions: monosulfide $M e_{1-x} \mathrm{~S}(\mathrm{Mss})$, intermediate $M e_{1+x} \mathrm{~S}(\mathrm{Iss})$ and bornite $\left(\mathrm{Bn}_{\mathrm{ss}}\right)$ solid-solutions, of which Iss is the main concentrator of the light PGE (Peregoedova \& Ohnenstetter, in press). Microparageneses of multiphase inclusions in Pt-Fe alloy composed of vysotskite, palladian cooperite, vasilite, and 
other sulfides of Pt and Pd in a chalcopyrite-bornite matrix occur rather commonly in other Alaskan-type sources at Durance, France (Johan et al. 1990), in placers of Siberia (Tolstykh \& Krivenko1994), in southern Burma (Hagen et al. 1990), for example. The difference is only in the degree of isomorphous substitution, and the variable stoichiometry of sulfides from low-sulfide (vasilite) to high-sulfide (malanite), depending on local sulfur fugacity at the time of their crystallization.

The presence of two minerals, each of which are solid solutions [irarsite with a sperrylite component $\left(\mathrm{IrAsS}-\mathrm{PtAs}_{2}\right)$ and sperrylite with a hollingworthite component $\left.\left(\mathrm{PtAs}_{2}-\mathrm{RhAsS}\right)\right]$ suggests the existence of an intermediate unstable high-temperature solid-solution, $(\mathrm{Ir}, \mathrm{Pt}, \mathrm{Rh})(\mathrm{S}, \mathrm{As})_{2}$. It could crystallize concurrently with platinum, with further decomposition into sperrylite and irarsite of an early generation, differing from late generations in the presence of components dissolved in the primary solid-solution, and partial deviation from stoichiometry. Similar observations were made earlier in connection with ultrabasic rocks in ophiolite complexes, where laurite was shown to contain the irarsite component, (Ir,Ru,Os)(S,As) 2 (Tolstykh et al. 1999).

Solid solutions in minerals from different geological settings usually reflect the specific features of the source. Cooperite and vysotskite placers of the Pustaya River, similar to cooperite of the Gusinogorsk massif in the Urals (Begizov et al. 1975) and the placers of northern Burma (Cabri et al. 1996), do not contain $\mathrm{Ni}$, compared to these minerals from stratiform intrusions (Cabri et al. 1978). However, they do contain $\mathrm{Cu}$, which is considered one of the features specific to the Alaskantype massifs. The Pd minerals keithconnite, stibiopalladinite, and rhodarsenide are characterized by $\mathrm{Pt}$ substitution for Pd, which is typical of zoned ultrabasic rocks and related placers (Cabri et al. 1996, Legendre \& Augé 1992, Gornostayev et al. 1999) rather than of stratiform intrusions.

\section{Elements of the Genetic Model}

On the basis of the relationship among mineral phases and a comparison of mineral compositions with results of experimental studies, a genetic model of the ore-forming system can be developed to describe the evolution of platinum mineralization in massifs in the basin of the Pustaya River. From the metal-rich melt undersaturated with $\mathrm{S}$ and depleted in refractory elements, the first phase to crystallize was osmium left over in the melt after fractionation of the major portion of refractory elements at the cumulate stage. The high concentration of $\mathrm{Pt}$ in native osmium (up to 10 at.\%) suggests that the temperature of crystallization was not less that $850^{\circ} \mathrm{C}$ (Slansky et al. 1991). At the next stage, platinum separated in the form of an alloy with iron. The last portions of melt, enriched in copper and saturated in volatiles, migrated into the marginal facies, enriching them in palladium. Part of this residual melt was localized in gas vacuoles with further crystallization, according to the model of PGE behavior in a sulfide system described by Peregoedova (1999). Vysotskite can be expected to separate from such a $\mathrm{Cu}$-enriched residual melt at a temperature below $840^{\circ} \mathrm{C}$ (Peregoedova 1999). The PtS component in Pustaya River vysotskite attains $26 \mathrm{~mol} . \%$, but it is known that at $800^{\circ} \mathrm{C}$, vysotskite may dissolve no more than 24 mol.\% PtS (Cabri et al. 1978). The Pustaya River vysotskite thus probably formed at a temperature somewhat higher than $800^{\circ} \mathrm{C}$. Pd-bearing Iss and $\mathrm{Bn}_{\mathrm{ss}}$ were produced on further cooling, and subsolidus transformations at temperatures between $760^{\circ}$ and $550^{\circ} \mathrm{C}$ led to vasilite and palladian cooperite and vysotskite as products of exsolution (Peregoedova 1999, Peregoedova \& Ohnenstetter, in press). Decomposition structures of this type are observed in the microparageneses, except that instead of $\mathrm{Pd}_{16} \mathrm{~S}_{7}$ and $(\mathrm{Pd}, \mathrm{Ni}) \mathrm{S}$, the S-undersaturated sulfide $(\mathrm{Pd}, \mathrm{Cu}, \mathrm{Pt})_{3} \mathrm{~S}$ crystallizes. Sulfur fugacity, $\log f\left(\mathrm{~S}_{2}\right)$, was no more than $10^{-4} \mathrm{~atm}$. Bornite solid-solution is the last to decompose, with the formation of chalcopyrite and bornite that fill the remaining space between other phases.

Finally, at the postmagmatic stage, the PGM assemblages were transformed under the influence of $\mathrm{Cu}$ - and $\mathrm{S}$-saturated fluids. It is at this point that the $\mathrm{Pd}$-free rims of $\mathrm{PtCu}, \mathrm{Pt}_{3} \mathrm{Cu}$, and cooperite formed.

The proposed model of the development of the ore system certainly does not explain the wide variety of natural parageneses related to zoned ultrabasic rocks of the Alaskan type, but it does show the general sequence of formation of the PGE minerals. One aspect of our model, a consequence of the sequence of formation of the PGM minerals, contradicts the proposal that isoferroplatinum cristallizes later that the other PGM ( $c f$. Legendre \& Augé 1992).

\section{Conclusions}

1. The placers of the Pustaya River occur within a belt of zoned ultrabasic rocks of Uralian or Alaskan type. In the drainage basin of the river, there are massifs of clinopyroxenite-dunite showing a limited degree of erosion and elevated concentration of Pd in magnetite clinopyroxenites. These massifs are the source of the platinum placers.

2. The PGM concentrate consists predominantly $(99.5 \%)$ of platinum grains with a considerable Pd content in the majority of them. The palladium concentration in grains of Pt-Fe alloy is typical of weakly eroded massifs.

3. The grains of Os-Is-Ru alloy in this association, included in grains of platinum, consist of native osmium. The compositions define an osmium trend that contrasts with the ruthenium trend characteristic of ultrabasic rocks in ophiolitic complexes (Krivenko \& Tolstykh 1994).

4. Cooperite from the Pustaya River suite does not contain $\mathrm{Ni}$, but it does contain $\mathrm{Cu}$ in solid solution. The 
Pd minerals keithconnite, stibiopalladinite and rhodarsenide are characterized by Pt substitution for Pd, which is typical of occurrences in zoned ultrabasic rocks of the Alaskan-type massifs.

5. Considering the majority of features, the mineral assemblage from the Pustaya River can best be compared with the placers of northern Burma and Ecuador and, to some extent, with those of the Durance, Fifield, Jubdo localities and, in Russia, with Kuznetzk Alatau, Koryakia, and Chukotka.

\section{ACKNOWLEDGEMENTS}

We express our sincere thanks to Dr. Yu.G. Lavrent'ev for providing excellent analytical procedures, to analysts V.M. Chubarov (Institute of Volcanology, Petropavlovsk-Kamchatskii), L.N. Pospelova (UIGGM, Novosibirsk), and S.A. Yurkovskiy for the computer software to manipulate the analytical data. A. Peregoedova and G.R. Kolonin are thanked for fruitful discussions. The authors greatly acknowledge the constructive comments by R.F.Martin, G. Garuti, associate editor, and O. Legendre and M. Nakagawa, referees. The work was partly supported by the research project Mineral Resources and Northern Wellbeing, Thule Institute, University of Oulu.

\section{REFERENCES}

Agafonov, L.V., Lebedev, V.I. \& Cherezov, A.M. (1998): The Minerals of Native Metals from the Placer of the Neozhidanniy Stream (Tuva) (K.S. Kuzhuget, ed). Russian Acad. of Sciences, Kyzyl, Russia (in Russ.)

Atanasov, A.V. (1990): Vasilite, $(\mathrm{Pd}, \mathrm{Cu})_{16}(\mathrm{~S}, \mathrm{Te})_{7}$, a new mineral species from Novoseltsi, Bulgaria. Can. Mineral. 28, 687-689.

Augé, T. \& Legendre, O. (1992): Pt-Fe nuggets from alluvial deposits in eastern Madagascar. Can. Mineral. 30, 983-1004.

\& Maurizot, P. (1995): Stratiform and alluvial platinum mineralization in the New Caledonia ophiolite complex. Can. Mineral. 33, 1023-1045.

Barkov, A.Yu., Lednev, A.L.\& Men'shikov, Yu.P. (1992): Some regularities in the distribution and compositional variation of minerals of the platinum-group elements from the Lukkulaisvaara Massif (northern Karelia). Dokl. Akad. Nauk SSSR 323, 539-544 (in Russ.).

Batanova, V.G. \& Astrakhantsev, O.V. (1994): Island-arc mafic-ultramafic plutonic complexes of North Kamchatka. In Abstract Proc. 29th Int. Geol. Congress. D, 129-143.

Begizov, V.D., BorisenKo, L.F.\& UsKov, E.D. (1975): Sulphides and natural solid solutions of PGE from ultramafic rocks of the Gusevogorsk massif (the Urals). Dokl. Acad. Sci. USSR, Earth Sci. Sect. 225, 134-137.
Betekhtin, A.G. (1935): Platinum and other Minerals of PGE Group. Akad. Nauk SSSR, Moscow, Russia (in Russ).

CABRI, L.J. \& FeAther, C.E. (1975): Platinum-iron alloys: a nomenclature based on a study of natural and synthetic alloys. Can. Mineral. 13, 117-126.

HARRIS, D.C. \& WEISER, T.W. (1996): Mineralogy and distribution of platinum-group mineral (PGM) placer deposits of the world. Explor. Mining Geol. 5, 73-167.

\& LAFLAMME, J.H.G. (1981): Analyses of minerals containing platinum-group elements. In Platinum-Group Elements: Mineralogy, Geology, Recovery (L.J. Cabri, ed). Can. Inst. Mining Metall., Spec. Vol. 23, 153-173.

, Stewart, J.M., Turner, K. \& SKInNer, B.J. (1978): On cooperite, braggite, and vysotskite. Am. Mineral. 63, 832-839.

Rowland, J.F., Laflamme, J.H.G. \& Stewart, J.M. (1979): Keithconnite, telluropalladinite and other PdPt tellurides from the Stillwater complex, Montana. Can. Mineral. 17, 589-594.

DALTRY, V.D.C. \& WiLson, A.H. (1997): Review of platinumgroup mineralogy: compositions and elemental associations of the PGE minerals and unidentified PGE-phases. Mineral. Petrol. 60, 185-229.

Distler, V.V., Malevskiy, A.Yu. \& Laputina, I.P. (1977): Distribution of the platinoids between the pyrrhotite and pentlandite in crystallization of the sulphide melt. Geochem. Int. 14(11), 30-40.

Dmitrenko, G.G. (1994): Minerals of Platinum-Group Elements from Alpine-Type Ultramafic Rocks. SBKNII DBO, Russian Academy of Sciences Publishing, Magadan, Russia (in Russ.).

El-Boragy, M. \& SchUbert, K. (1971): Uber einige Variaten der NiAs-Familie in Mischungen des Palladiums mit BElementen. Z. Metallkunde 63, 314-323.

EvstigneEva, T.L., KudRyavtSEV, A.S. \& RudasheVSKIY, N.S. (1992): Minerals of the platinum-group elements from Jubdo (Ethiopia): new data. Mineral. Zh. 14, 29-41 (in Russ.).

FEATHER, C.E. (1976): Mineralogy of platinum-group minerals in the Witwatersrand, South Africa. Econ. Geol. 71, 1399-1428.

Genkin, A.D., Evstigneeva, T.L., Vyal'sov, L.N. \& LAPUTINA, I.P. (1985): Kharaelakhite (Pt, Cu, Pb,Fe,Ni) ${ }_{9} \mathrm{~S}_{8}$, a new sulphide of platinum, copper and lead. Mineral. $\mathrm{Zh}$. 7(1), 78-83 (in Russ.).

Gornostayev, S,S. (1994): Occurrences and Compositions of Platinum-Group Minerals in the Aluchin Horst, Western Chukotka. Ph.D. thesis, Univ. of Voronezh, Voronezh, Russia (in Russ.). 
Crocket, J.H., Mochalov, A.G. \& LaAjoki, K.V.O. (1999): The platinum-group minerals of the Baimka placer deposits, Aluchin horst, Russian Far East. Can. Mineral. 37, 1117-1129.

Hagen, D., Weiser, T. \& Thay, T. (1990): Platinum-group minerals in Quaternary gold placers in the upper Chindwin area of northern Burma. Mineral. Petrol. 42, 265-286.

Izokh, A.E., Maiorova, O.N. \& Lavrent'ev, Yu.G. (1992): Minerals of the platinum metals in the Nomgon troctolite anorthosite - gabbro intrusive (Mongolia). Geol. Geophys. 33(1), 37-43 (in Russ.).

Johan, Z., Ohnenstetter, M., Fisher, W. \& Amossé, J. (1990): Platinum-group minerals from the Durance River alluvium, France. Mineral. Petrol. 42, 287-306.

SLANSKy, E., BARRon, L.M. \& SuPPEL, D. (1989): Platinum mineralization in the Alaskan-type intrusive complexes near Fifield, New South Wales, Australia. 1. Platinum-group minerals in clinopyroxenites of the Kelvin Grove Prospect, Owendale intrusion. Mineral. Petrol. 40, 289-309.

, Slansky, E. \& Ohnenstetter, M. (1991): Isoferroplatinum nuggets from Milverton (Fifield, N.S.W., Australia): a contribution to the origin of PGE mineralization in Alaskan-type complexes. C.R. Acad. Sci. Paris 312, 55-60.

Kozin, N.N., Loginov, V.A., Zaitzev, V.P., Kozlov, A.P. \& Sidorov, E.G. (1999): The platinum mining activities of Koryak geology mining company in northern Kamchatka. Prospectors and Developers Association Convention 99, 9-10 (abstr.).

Krivenko, A.P \& Tolstykh, N.D. (1994): Composition of native minerals in Os-Ir-Ru system and conditions of their formation. Seventh Int. Platinum Symp., 57 (abstr.).

, Nesterenko, G.V. \& Lazareva, E.V. (1994): Types of mineral associations of platinoids in auriferous placers of the Altai-Sayan region. Russ. Geol. Geophys. 35(1), 58-65.

, VeSElovsKiY, N.N. \& MAYOROVA, O.N. (1991): Gold-bearing tellurides of PGE and palladium-bearing gold in gabbronorite of Panskiy massif in Kola Peninsula. Dokl. Acad. Sci. USSR, Earth Sci. Sect. 319, 187-192.

Kutyev, F.S., Sidorov, E.G. ReZnichenko, V.S. \& SEMyonov, V.L. (1991): New data about platinoids in zoned ultrabasic complexes of the Southern part of Koryak Highland. Dokl. Akad. Nauk USSR 317, 1458-1461 (in Russ.).

LAVRent'ev, Yu.G. \& Usova, L.V. (1994): New version of the KARAT program for quantitative X-ray spectral microanalysis. J. Anal. Chem. 49, 462-468 (in Russ.).

Legendre, O. \& AugÉ, T. (1992): Alluvial platinum-group minerals from the Manampotsy area, East Madagascar. Aust. J. Earth Sci. 39, 389-404.
Makovicky, M., Makovicky, E. \& Rose-Hansen, J. (1986): Experimental studies on the solubility and distribution of platinum group elements in base-metal sulphides in platinum deposits. In Metallogeny of Basic and Ultrabasic Rocks (M.J. Gallagher, R.A. Ixer, C.R. Neary \& H.M. Prichard, eds.). The Institution of Mining and Metallurgy, London, U.K. (415-425).

Matkovic, P., El-Boragy, M. \& Schubert, K. (1976): Kristallstruktur von $\mathrm{Pd}_{16} \mathrm{~S}_{7}$. J. Less-Common Metals 50, 165-176.

Nekrasov, I.Ya., Ivanov, V.V., Lennikov, A.M., OKTyaBR'SKIY, R.A., ZALISHAK, B.L., SAPIN, V.I. \& TASKAYEV, V.I. (1991): Composition of Pt-Fe solid solution, as indicator of the level of erosion of the platinum-bearing ring alkaline-ultrabasic intrusions. Dokl. Akad. Nauk SSSR 321, 1049-1053 (in Russ.).

LENNIKOV, A.M. \& OKTYABR'SKIY, R.A. (1994): Petrology and Platinum Mineralization of the Ring Alkaline-Ultrabasic Complexes. Nauka, Moscow, Russia (in Russ.).

Nixon, G.T., Cabri, L.J. \& Laflamme, J.H.G. (1990): Platinum-group-element mineralization in lode and placer deposits associated with the Tulameen Alaskan-type complex, British Columbia. Can. Mineral. 28, 503-535.

Peregoedova, A.V. (1999): Physicochemical Behaviour of Pt and Pd in the Process of the Crystallization of $\mathrm{Fe}, \mathrm{Ni}, \mathrm{Cu}$ Bearing Sulphide Melts and Following Subsolidus Transformations (According to Experimental Data). Ph.D. thesis, UIGGM SB RAS, Novosibirsk, Russia (in Russ.).

\& Ohnenstetter, M. (2001): Collectors of Pt, Pd and $\mathrm{Rh}$ in a S-poor $\mathrm{Fe}-\mathrm{Ni}-\mathrm{Cu}$ sulfide system at $760^{\circ} \mathrm{C}$ : experimental data and application to ore deposits. Can. Mineral. 39 (in press).

Shashkin, V.M. \& Botova, M.M. (1989): Mineralogy and origin of the metals of platinum group in the alkalineultrabasic complexes. In Abstr., 28th Int. Geol. Congress, 183-189.

Sidorov, E.G. (1995): Platinum occurrences in ultramafic massifs of the Koryak-Kamchatka region. In Geology and Mineral Deposits of the Russian Far East. Alaska Miners Assoc., Spec. Vol. 1, 36-39.

Zaitsev, V.P. \& Melkomukov, V.N. (1997): Recent placer platinum activities in the Koryak-Kamchatka platinum belt, northern Russia. In Mining - Alaska's Growth Industry. Alaska Miners Assoc., Annual Convention, 50 (abstr.).

Skinner, B.J., Luce, F.D., Dill, J.A., Ellis, D.E., Hagan, H.A., Levis, D.M., Odell, D.A., SverJensky, D.A. \& WILLIAMS, N. (1976): Phase relations in ternary portion of the system Pt-Pd-Fe-As-S. Econ. Geol. 71, 1469-1475.

Slansky, E., Johan, Z. , OHNEnStetter, M., BARRon, L.M. \& SUPPEL, D. (1991): Platinum mineralization in the Alaskan- 
type intrusive complexes near Fifield, N.S.W., Australia. 2. Platinum-group minerals in placer deposits at Fifield. Mineral. Petrol. 43, 161-180.

Slobodskoy, R.M. (1981): Elemento-organic Compounds in the Magmagene and Ore-Forming Processes (Yu.A. Kuznecov \& V.N. Sharapov, eds.). Nauka, Novosibirsk, Russia (in Russ.).

Tarkian, M., Krstić, S., Klaska, K.-H. \& Liessmann, W. (1997): Rhodarsenide, (Rh,Pd) ${ }_{2}$ As, a new mineral. Eur. J. Mineral. 9, 1321-1325.

TOLSTYKH, N.D.\& KRIVEnKo, A.P. (1994): On the composition of sulphides containing platinum-group elements. Zap. Vses. Mineral. Obshchest. 123(2), 41-49 (in Russ.).

\& (1997): Platinum-group minerals in the Inagli placer (Aldan shield). Russ. Geol. Geophys. 38, 765774 .

\& BATURIN, S.G. (1996): Compositional features of native platinum from different mineral assemblages of platinum-group elements. Russ. Geol. Geophys. 37(3), 35-43.
\& Pospelova, L.N. (1997): New compounds of Ir, Os and Ru with selenium, arsenic and tellurium. Eur. J. Mineral. 9, 457-465.

Lapukhov, A.S., KrivenKo, A.P., Lazareva, E.V. (1999): Minerals of platinum group elements from gold placers of north-east Salair. Russ. Geol. Geophys. 40, 900910 (in Russ.).

Weiser, T. \& Schmidt-Thomé, M. (1993): Platinum-group minerals from the Santiago River, Esmeraldas Province, Ecuador. Can. Mineral. 31, 61-73.

Zaitsev, V.P., Loginov, V.A., Melkomukov, V.N., VoroGUShin, N.T., Vildanova, E.Y, Litvinov, A.F., PatoKa, M.G. \& Sidorov, E.G. (1998): The new biggest platinum province of NW Pacific. Eighth Int. Platinum Symp., 461463 (abstr.).

Received September 28, 1999, revised manuscript accepted June 29, 2000 